\author{
Agata K. Markowska \\ University of Warsaw - Faculty of Geography and Regional Studies \\ - Chair of Didactics of Geography and Tourism \\ 00-927 Warsaw, Krakowskie Przedmieście 30 \\ e-mail: a.k.markowska@uw.edu.pl
}

\title{
GEOGRAPHICAL PATHS AS AN AUXILIARY DIDACTIC RESOURCE - A STUDY PROPOSAL
}

\begin{abstract}
Didactic paths play a very important part in modern education, on the primary school level as well as at universities. Beside other things, they let students compare book knowledge with the real world. Unfortunately, there are only a few geographical didactic paths, as opposed to those in history or science.

The new offer for preparing methodological geographical paths begins with an analysis of documents as a curriculum model or a syllabus with chosen items to be taught which can be discussed during outdoor lessons and finally examines the area which fulfils a large number of requirements.

It is possible that in this way of preparing methodological geographical paths the boring, monotonous area will give many possibilities to discuss teaching items.
\end{abstract}

Key words: didactic paths, curriculum model, program basis, teaching syllabus, teaching content.

Objective didactic paths perform an essential part in present education. No wonder they are a didactic resource considered by teachers to be indispensable in the teaching process. Classes conducted in terrain make it possible for pupils to confront textbook knowledge with reality and they motivate them to attentive observation of the surrounding scenery and acquiring certain practical skills, such as taking measurements or readings. Outside the classroom, the teacher has the possibility of steering the observations made by pupils, that is planned and conscious perception of objects, phenomena and processes set in the surrounding scenery as well as helping in inter- 
preting the results (Piskorz 1997). Both for teachers and pupils, this form of classes is more attractive than typical classroom lessons, in spite of the fact that outdoor classes require greater commitment and preparation. Young people are more active and better remember field classes, the phenomena they observed, measured or analysed. Also, the teacher has the possibility of conducting more interesting and varied lessons. Simultaneously, field occupations play an important part not only in the process of educating pupils, but also in the educational process itself (Hakke, Nonas 1977). The pupils learn individually and the team works together gathering reliable records. They develop proper behaviour skills in public places as well as in places of religious cult. They also begin to care about culture goods as well as about Nature.

A specific form of field classes are didactic routes actually existing in terrain, with appointed stations where we can discuss with pupils numerous issues of the didactic content (Angiel 2005). They are usually described in the form of brochures, more seldom are marked with charts.

Unfortunately, at present, geographical paths comprise a small percentage of paths in general (Pulinowa 1995). Majority are natural (eg. Wójtowicz, Wójtowicz 1993), historical, geological and ecological paths, as well as paths combining these disciplines (np. Irla 1994; Łukasiewicz 1993; Kuśmierska et al. 1993). Though some of thesepaths, like for instance, the natural ones concern questions closely connected with geography, e.g. issues of soil types and vegetation.

As varied as is the subject matter of the paths so are the different reasons for creating them and their authors.

Didactic paths marked throughout national and landscape parks are easily accessible, designed for a wider group of recipients, not only for teachers and pupil groups, but also for individual tourists. Generally, the routes harmonize with tourist routes and they run through the most attractive parts of a given protected area. For example, the Kampinos National Park possesses four traced didactic paths, and the Hollycross Mountains can be proud of the rich choice of didactic paths on such varied subject matters as history, ecology, sociology and geological issues.

Also, forest inspectorates work out didactic paths with the aim of discussing questions focusing on the maintenance of forest economy and the use of forests, principles of human behaviour in the forest, 
delivery of information about its structure and illustrating threats as well as methods of nature protection.

Wanting to increase their tourist attractiveness, authorities of many administrative districts decide to map out didactic paths in their area, sometimes in the framework of competition.

The last, very numerous group of authors of didactic paths, includes teachers of different subjects who often mark routes as part of the requirements to formalise their professional advancement. Didactic paths designed by teachers usually are in the closest neighbourhood of school and they allow to discuss program content from diverse disciplines.

As we can see from the above mentioned examples, majority of didactic geographical paths either in the mountains, upland or lowland areas were chosen because of characteristic terrain features or their vicinity to schools. This is good because such paths illustrate the specific type of scenery as well as the cultural uniqueness the of region. However, there also exist disadvantages of such an approach because by exposing the uniqueness of a place the teacher can realize limited program content. The same happens in other countries. The didactic paths in the United States mainly exist in national parks, which portray the uniqueness of nature and in Great Britain, where many questions are discussed during outdoor lessons. There, the teacher, depending on conditions of the environment, decides which of them will be discussed in the terrain (Hindson 1991).

Often, however, the teacher both in Poland and in other countries, affirms that in the closest neighbourhood there is nothing interesting to show, so he relinquishes going out in the terrain. Often, because pupils cannot afford to pay for class trips to more varied terrains, even this form of field activities becomes impossible.

There also are formal and organisational obstacles that force teachers to resign from the idea of going out in terrain. The small number of hours designated to teaching geography and different "classic" subjects results in the fact that both management and teachers of different subjects reluctantly agree to field trips during teaching hours, because this means loss of lesson hours and creates problems with realization of different programme content. The number of classes is the next problem. In Poland, often with over 30 people in a class, it is necessary to have additional persons to take care of the pupils. For the above mentioned reasons, teachers of different subjects do not want to participate as group chaperones unless they dedicate their 
private time, which happens unusually seldom. Moreover, teachers avoid going out with pupils beyond the school area because of frequent educational difficulties and problems with safeguarding a numerous group in an open space

At this moment, the question arises as how to increase the efficiency of geographic education in terrain. Instead of choosing the possibility given by the terrain as the starting point, it would be good to experience of "finishing construction of the path in terrain". In the Author's opinion, one should begin planning the geographical didactic paths from analyses of the obligatory programmes in a particular country. For example, in Poland one should start from a comparative analyses of the program framework, the chosen programmes of teaching geography and examination standards of the secondary-school final exams. Subsequently, from these documents should be chosen the content suitable for realization, during particular lessons carried out on didactic paths. It maybe a difficult undertaking because the program framework is very general, allowing great liberty to the textbook authors (the program content) as well as to the publishers (the graphic form of textbooks and the teaching programmes). This leads to the fact that, in the program framework, content may be treated in different ways, in individual teaching programmes.

The last step is finding the proper terrain, if possible near the school, which to the largest possible degree, would fulfil the teaching programme requirements. If programmes for teaching geography and requirements of external examinations could together be regarded as the starting point in constructing didactic paths, it would turn out that even the seemingly monotonous and dull areas give great possibilities of discussing geographic content.

What geographic content can we realize in the terrain of Central European conditions?

These, among others, are the following:

- map and its practical use;

- external processes (the eolian, the fluvial, mass movements) formative scenery of the Earth;

- elements of river valley or the slope processes (the profile of a slope);

- real vegetation;

- interaction Earth - man: direct and indirect influence of man on the natural environment and of the natural environment on man; 
- soil types and their agricultural usefulness;

- forms of use of the terrain;

- social classes and social transformations;

- renewable and non-renewable sources energy;

- tourism and recreation;

- development of sectors;

So far, in reference to the existing paths, physical geography is the most often realized subject while socio-economic questions are almost always skipped. This is not surprising because physical-geographic content is more easily found in the terrain. We can always discuss such issues as identification of clouds, soil types, vegetal cover or identification of elements of the hydrographic network. It is considerably harder to notice the anthropogenic elements in the terrain because they seem to comprise components of our surroundings. We come across them every day, we are accustomed to them and we do not perceive them as part of geographic space. Almost always, in the neighbourhood, teachers come across shops with radio and TV equipment and with household goods (development of hi-tech industry), sun collectors on road signs (an alternative sources of energy), car workshops and shops (development of sector services), public transport stops (circular transportation and rail).

The Author's proposal discussed above, concerning development of didactic geographical paths has both advantages and disadvantages. One of its disadvantages is certainly the fact that it is a labour-consuming method, demanding considerable commitment on the part of the teacher who alone has to design the route and prepare the practice cards for pupils.

Among the advantages is the fact that the new method allows for a discussion of the diversified content, including a range of issues in socio-economic geography. In addition, there is a possibility of conducting lessons everywhere, by every geography teacher, without regard to the level of education and partly without regard to the obligatory teaching programme which may be modified accordingly. In general, it is possible to conduct geography lessons or summing up, to deliver the acquired knowledge from particular sections. 


\section{REFERENCES}

Irla J., 1994, Przyrodniczo-geologiczna ścieżka dydaktyczna Pińczów - Skowronno [The Pińczów-Skowronno ecological and geological didactic path; in Polish], Zarząd Świętokrzyskich i Nadnidziańskich Parków Krajobrazowych, Kielce.

Kuśmierska A. i in., 1993, Przyrodniczo-historyczna ścieżka dydaktyczna $w$ Sieradowickim Parku Krajobrazowym i jego otulinie [Ecological and historical didactic path in the Sieradowicki Landscape Park and it's protection zone; in Polish], Zarząd Świętokrzyskich i Nadnidziańskich Parków Krajobrazowych, Kielce.

Łukasiewicz Z., 1993, Przyrodniczo-geologiczna ściė̇ka dydaktyczna Bogucice Grabowiec - Gacki, [The Bogucice - Grabowiec - Gacki ecological and geological didactic path; in Polish], Zarząd Świętokrzyskich i Nadnidziańskich Parków Krajobrazowych, Kielce.

Hakke Cz., Nonas N., 1977, Wycieczki i zajęcia terenowe [Excursions and fields activities], WSiP, Warszawa.

Hindson J., 1991, Zajęcia w terenie [Field activities; in Polish], Geografia w Szkole, 5/1991: 288-292.

Makowska D., 1994 - Ćwiczenia terenowe w historycznych miastach środkowej Anglii [Field practice in historical cities of central England; in Polish], Geografia $w$ Szkole, 1/1994, Warszawa.

Piskorz S., 1997, Zarys dydaktyki geografii [An outline of geographical didactics; in Polish], Wydawnictwo Naukowe PWN, Warszawa.

Wójtowicz B., Wójtowicz J., 1993, Przyrodnicza ścieżka dydaktyczna Łagów - Dol. Eagowicy - Wawóz Dule - Jaskinia Zbójecka [The Łagów ecological didactic path - Łagowica Valley - Dule Gorge - Zbójecka Cave; in Polish], Zarząd Świętokrzyskich i Nadnidziańskich Parków Krajobrazowych, Kielce. 